\title{
Kaitan Pelaksanaan Pengalaman Lapangan Industri terhadap Kesiapan Memasuki Dunia Kerja pada Mahasiswa Jurusan Teknik Otomotif
}

\author{
Ahmad Ikwal $^{1 *}$ Hasan Maksum $^{1}$ dan Toto Sugiarto ${ }^{1}$ \\ ${ }^{1}$ Jurusan Teknik Otomotif, Fakultas Teknik, Universitas Negeri Padang \\ Jl. Jalan Prof. Dr. Hamka, Air Tawar Padang, Sumatera Barat \\ *e-mail: ahmadikwal@gmail.com \\ (Diajukan: 14 Agustus 2021, direvisi: 31 Agustus 2021, disetujui: 02 September 2021)
}

\begin{abstract}
Abstrak
Artikel ini membahas mengenai hubungan pelaksanaan pengalaman lapangan industri terhadap kesiapan memasuki dunia kerja pada mahasiswa Jurusan Teknik Otomotif Fakultas Teknik Universitas Negeri Padang. Kuesioner disebarkan pada responden dan kemudian diolah secara statistic untuk didapati korelasional antar data. Hasil penelitian menunjukkan terdapat pengaruh yang signifikan antara pelaksanaan pengalaman lapangan industri terhadap kesiapan memasuki dunia kerja pada mahasiswa Jurusan Teknik Otomotif FT-UNP, kemudian juga terungkap bahwa terdapat kontribusi pelaksanaan pengalaman lapangan industri terhadap kesiapan memasuki dunia kerja mahasiswa jurusan teknik otomotif ft-unp sebesar $68,6 \%$.
\end{abstract}

Kata Kunci: pengalaman lapangan industri, kesiapan memasuki dunia kerja, penelitian korelasional.

\begin{abstract}
This article discusses the relationship between the implementation of industrial field experience and readiness to enter the world of work in students of the Automotive Engineering Department, Faculty of Engineering, State University of Padang. Questionnaires were distributed to respondents and then statistically processed to find correlations between data. The results showed that there was a significant influence between the implementation of industrial field experience on readiness to enter the workforce for students of the Automotive Engineering Department FT-UNP, then it was also revealed that there was a 68,6\% contribution from the implementation of industrial field experience to the readiness to enter the world of work for students.
\end{abstract}

Keywords: industrial field experience, readiness to enter the workforce, correlational research. 


\section{PENDAHULUAN}

Seiring dengan laju pembangunan dewasa ini banyak hal yang perlu ditingkatkan yang menyangkut dari semua bidang diantaranya bidang perekonomian, dan industri dengan tujuan untuk meningkatkan kesejahteraan masyarakat. Laju pembangunan tersebut menuntut masyarakat untuk menjadi tenaga kerja ahli dan terampil, serta memiliki watak dan kepribadian yang tangguh. Hal ini menjadi tanggung jawab besar bagi sistem pendidikan untuk mencetak generasi-generasi siap pakai dilapangan pekerjaan. Fakultas Teknik Universitas Negeri Padang (FT-UNP) sebagai salah satu lembaga pendidikan yang bertugas menghasilkan tenaga kerja yang profesional dalam bidang supervisi, berupaya melaksanakan program-program pendidikan yang bertujuan untuk menghasilkan lulusan yang tidak hanya memahami ilmu pengetahuan dan teknologi secara konseptual dan teoritis di perkuliahan, tetapi juga mampu mengaplikasikan dan mengembangkan ilmu tersebut di dunia industri secara praktis.

Pengalaman Lapangan Industri (PLI) merupakan jembatan penghubung antara industri dengan lembaga pendidikan. Bertolak dari fenomena di atas pelaksanaan Pengalaman Lapangan Industri bagi mahasiswa sangatlah penting untuk menambah wawasan di dunia industri, sebagai acuan dalam persiapan memasuki dunia kerja. Di samping itu, pelaksana PLI dapat memahami, serta mengenal lebih jauh implementasi disiplin ilmu sesuai dengan program studi yang dijalani. Lebih dari pada itu, pelaksanaan PLI memberi masukan bagi mahasiswa dalam hal menemukan, merekayasa dan mengembangkan objek yang ditemukan di industri, sehingga diharapkan bermanfaat bagi pengembangan industri maupun masyarakat. Indikator kualitas lembaga pendidikan yang bertugas menghasilkan tenaga kerja yang profesional ini dapat dilihat dari banyaknya lulusan yang dapat bekerja di dunia kerja serta waktu yang relatif pendek untuk mendapatkan pekerjaan. Untuk meningkatkan kesiapan mahasiswa dalam memasuki dunia kerja tersebut, mereka harus mengikuti latihan dan mempunyai pengalaman yang berorientasi langsung dengan lapangan kerja. Peningkatan kesiapan mahasiswa dalam memasuki dunia kerja tersebut dilaksanakan melalui Pengalaman Lapangan Industri, dimana mahasiswa belajar di dunia kerja maupun dunia industri yang telah mereka tentukan, guna mengetahui dunia kerja serta mempraktekkan ilmu yang telah mereka peroleh.

Oleh karena itu, dalam hal ini peneliti hanya fokus ke pada pelaksanaan PLI sebagai faktor yang mempengaruhi kesiapan kerja mahasiswa. Dari fenomena yang telah penulis paparkan di atas dapat disimpulkan bahwa PLI merupakan suatu pengalaman langsung untuk mahasiswa mengetahui dan mempelajari dunia kerja atau dunia industri, dengan pelaksanaan PLI diharapkan menimbuhkan sikap profesional bagi mahasiswa serta memiliki kemampuan kerja yang baik sehingga mahasiswa akan siap untuk memasuki dunia kerja.

Menurut Marwansyah dalam Wariati [1] pengalaman kerja adalah suatu pengetahuan, keterampilan, dan kemampuan yang dimiliki pegawai untuk mengembangkan tanggung jawab dari pekerjaan sebelumnya, indikator dari pengalaman kerja adalah : pengetahuan, keterampilan, kemampuan dan tanggung jawab. Pengalaman merupakan pengetahuan atau keterampilan yang diketahui dan dikuasai oleh seseorang sebagai akibat dari perbuatan atau pekerjaan yang telah dilakukan 
sebelumnya dalam jangka waktu tertentu. Seseorang dikatakan berpengalaman apabila telah memiliki tingkat penguasaan pengetahuan dan keterampilan yang relevan sesuai dengan bidang keahliannya. Menurut Oemar Hamalik [2] (2013:29) "pengalaman adalah sumber pengetahuan dan pengalaman diperoleh karena adanya interaksi antara individu dengan lingkungannya". Menurut Hamalik dalam Pratama dkk [3] praktik kerja industri merupakan suatu tahap profesional dimana seorang mahasiswa (peserta) yang hampir menyelesaikan studi (pelatihan) secara formal bekerja di lapangan dengan supervisi oleh seorang administrator yang kompeten dalam jangka waktu tertentu yang bertujuan untuk mengembangkan kemampuan melaksanakan tanggung jawab. Menurut Wibowo [4] menjelaskan bahwa praktik kerja industri "Merupakan bentuk kerja sama antara Perguruan Tinggi dengan industri yang selama ini dilakukan oleh Perguruan Tinggi dengan memberikan kepercayaan terhadap industri untuk membimbing mahasiswa mencapai kompetensi sesuai sesuai dengan kurikulum”. Menurut Djuwita [5] bahwa dunia kerja adalah suatu tempat melaksanakan pekerjaan oleh seseorang maupun kelompok untuk menghasilkan sesuatu sesuai dengan tujuan. Menurut Ginting [6] dunia kerja adalah suatu tempat atau wadah orang-orang berkmpul untuk bekerja bersama-sama.

\section{METODE}

Berdasarkan permasalahan dan tujuan yang ingin dicapai, jenis penelitian ini digolongkan kepada penelitian korelasional. Suharsimi [7] menjelaskan bahwa "penelitian korelasi adalah penelitian yang bertujuan untuk mengetahui hubungan antara dua variabel atau lebih". Adapun tujuan utama pada penelitian ini adalah untuk mengetahui Pengaruh Pelaksanaan Pengalaman Lapangan Industri Terhadap Kesiapan Memasuki Dunia Kerja Mahasiswa Teknik Otomotif FT-UNP.

\section{HASIL DAN PEMBAHASAN}

\section{Deskripsi Data}

Data penelitian ini meliputi 2 variabel yaitu variabel Pelaksanaan Pengalaman Lapangan Industri (x), dan kesiapan memasuki dunia kerja (y). Secara singkat deskripssi data dari kedua variabel dapat dilihat pada tabel di bawah ini.

Tabel 1. Data Hasil Analisis Deskriptif

\begin{tabular}{lccc}
\hline & & $\mathrm{X}$ & $\mathrm{Y}$ \\
\hline $\mathrm{N}$ & Valid & 55 & 55 \\
& Missing & 0 & 0 \\
Mean & & 132,7636 & 121,1636 \\
Std. Error of Mean & 1,39165 & 1,35233 \\
Median & 136,0000 & 121,0000 \\
Mode & 138,00 & 121,00 \\
Std. Deviation & 10,32072 & 10,02915 \\
Variance & 106,517 & 100,584 \\
Range & 48,00 & 48,00 \\
Minimum & 100,00 & 87,00 \\
Maximum & 148,00 & 135,00 \\
Sum & 7302,00 & 6664,00 \\
\hline
\end{tabular}




\section{Pengalaman Lapangan Industri}

Setelah diperoleh deskripsi data untuk pengalaman lapangan industri terlihat bahwa Mean (nilai rata-rata) 132,7636, Standar Deviasi 10, 32072, Mode 138, dan Median 136,0000, Minimum 100,00, Maximum 148,00, Range 48,00, dan Sum 7302,00. Tabel 2 berikut disajikan distribusi skor dan grafik histogram dari skor variabel X

Tabel 2. Distribusi Frekuensi Skor X

\begin{tabular}{ccc}
\hline Kelas Interval & Frekuensi & $\%$ \\
\hline $100-106$ & 1 & 1,82 \\
$107-113$ & 2 & 3,64 \\
$114-120$ & 6 & 10,91 \\
$121-127$ & 3 & 5,45 \\
$128-134$ & 13 & 23,64 \\
$135-141$ & 20 & 36,36 \\
$142-148$ & 10 & 18,18 \\
Total & 55 & 100 \\
\hline
\end{tabular}

\section{PENGALAMAN LAPANGAN INDUSTRI}

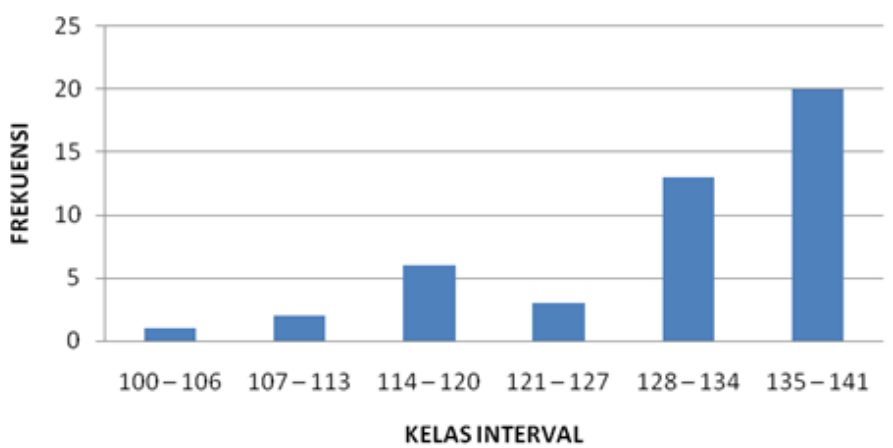

Gambar 1. Histogram Pengalaman Lapangan Industri

Dari perhitungan statistik dasar diketahui bahwa skor jawaban menyebar dari skor terendah 100 dan skor tertinggi 148, sehingga rentang nilai yang tersebar pada sampel adalah $148-100=48$ dan standar deviasi 10,32072 dan variance 106,517

$$
\text { Tingkat pencapaian }=\frac{132,7636}{5 \times 31} \times 100 \%=85,65 \%
$$

Untuk pengkategorian nilai pencapaian responden digunakan klasifikasi seperti pada tabel 3:

Tabel 3. Pengkategorian Nilai Pencapaian Responden

\begin{tabular}{cc}
\hline Tingkat Pencapaian & Keterangan \\
\hline $90 \%-100 \%$ & Sangat Tinggi \\
$80 \%-89 \%$ & Tinggi \\
$70 \%-79 \%$ & Sedang \\
$60 \%-69 \%$ & Kurang \\
$0 \%-59 \%$ & Sangat Kurang \\
\hline
\end{tabular}

Jadi dapat disimpulkan bahwa rata-rata tingkat pencapaian skor kepuasan belajar adalah $85,65 \%$ dan masuk kedalam kategori tinggi. Dari data ini dapat dikatakan 
bahwa Pelaksanaan Pengalaman Lapangan Industri Mahasiswa Teknik Otomotif FT-UNP secara umum adalah Tinggi.

\section{Kesiapan Memasuki Dunia Kerja}

Setelah diperoleh deskripsi data keseluruhan terlihat bahwa mean (nilai ratarata) 121,1636, Standar Deviasi 10,02915, Mode 7121,00 dan Median 121,0000, Minimum 87,00, Maximum 135,00, Range 48 dan Sum 6664,00. Pada tabel 4 disajikan distribusi skor dan grafik histogram dari skor variabel Y.

Tabel 4. Distribusi Frekuensi Data Y

\begin{tabular}{ccc}
\hline Kelas Interval & Frekuensi & $\%$ \\
\hline $87-93$ & 1 & 1,82 \\
$94-100$ & 2 & 3,64 \\
$101-107$ & 0 & 0 \\
$108-114$ & 7 & 12,73 \\
$115-121$ & 19 & 34,55 \\
$122-128$ & 11 & 20,00 \\
$129-135$ & 15 & 27,27 \\
Total & 55 & 100 \\
\hline
\end{tabular}

\section{KESIAPAN MEMASUKI DUNIA KERJA}

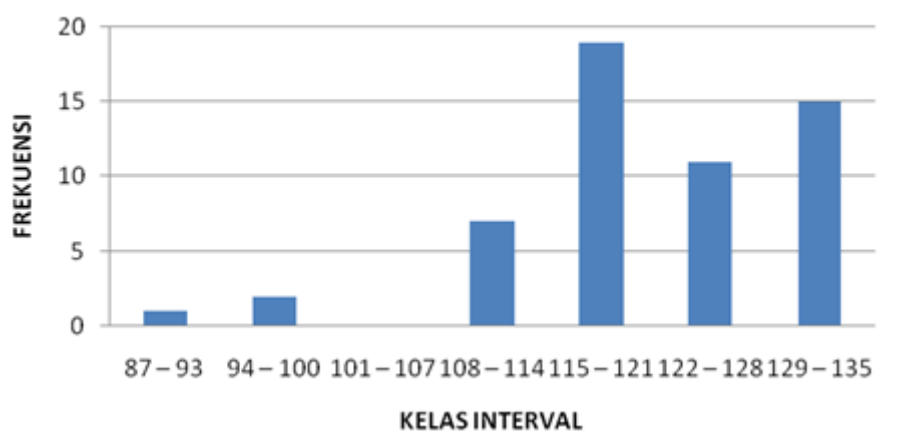

Gambar 2. Histogram Kesiapan Memasuki Dunia Kerja

Dari perhitungan statistik dasar hasil belajar diketahui bahwa skor jawaban menyebar dari skor terendah 87 dan skor tertinggi 135, sehingga rentang nilai yang tersebar pada sampel adalah $135-87=48$ dan standar deviasi 10,02195 dan variance 100,584. Tingkat pencapaian responden pada masing-masing variabel digunakan rumus:

$$
\text { Tingkat pencapaian }=\frac{121,1636}{5 \times 29} \times 100 \%=83,56 \%
$$

Untuk pengkategorian nilai pencapaian responden digunakan klasifikasi seperti pada tabel 5 .

Tabel 5. Pengkategorian Nilai Pencapaian Responden

\begin{tabular}{cc}
\hline Tingkat Pencapaian & Keterangan \\
\hline $90 \%-100 \%$ & Sangat Tinggi \\
$80 \%-89 \%$ & Tinggi \\
$70 \%-79 \%$ & Sedang \\
$60 \%-69 \%$ & Kurang \\
$0 \%-59 \%$ & Sangat Kurang \\
\hline
\end{tabular}

Jadi dapat disimpulkan bahwa rata-rata tingkat pencapaian skor kepuasan belajar adalah $83,56 \%$ dan masuk kedalam kategori tinggi. Dari data ini dapat dikatakan 
bahwa Kesiapan Memasuki Dunia Kerja Mahasiswa Teknik Otomotif FT-UNP secara umum adalah Tinggi.

\section{Uji Persyaratan Analisis}

Teknik Analsis yang digunakan dalam penelitian ini adalah teknik analisis korelasi. Analisis ini dapat dilakukan bila memenuhi persyaratan yaitu: uji normalitas, uji linieritas.

\section{Uji Normalitas}

Pengujian normalitas data penelitian dilakukan dengan menggunakan uji kolmogorov-smirnov (Uji K-S). Taraf signifikasi yang digunakan sebagai dasar distribusi data adalah $\alpha=0,05$, hasil perhitungan normalitas dapat dilihat pada Tabel 6.

Tablel 6. Uji Normalitas (Kolmogorov-Smirnov)

\begin{tabular}{llcc}
\hline & & $\mathrm{X}$ & $\mathrm{Y}$ \\
\hline $\mathrm{N}$ & & 55 & 55 \\
Normal Parameters(a,b) & Mean & 132,7636 & 121,1636 \\
& Std. Deviation & 10,32072 & 10,02915 \\
Most Extreme Differences & Absolute &, 159 &, 160 \\
& Positive &, 102 &, 084 \\
& Negative &,- 159 &,- 160 \\
Kolmogorov-Smirnov Z & & 1,182 & 1,187 \\
Asymp. Sig. (2-tailed) & &, 122 &, 119 \\
\hline
\end{tabular}

Berdasarkan tabel 6 , dapat dilihat bahwa nilai signifikasi untuk semua variabel lebih besar dari $\alpha=0,05$. Dengan demikian sebaran data berdistribusi normal.

\section{Uji Linieritas}

Hasil perhitungan uji linieritas dapat dilihat pada tabel 7.

\begin{tabular}{|c|c|c|c|c|c|c|c|}
\hline & & $\mathrm{X}$ & Sum of Squares & df & Mean Square & $\mathrm{F}$ & Sig. \\
\hline \multirow{5}{*}{$\begin{array}{l}\mathrm{Y}^{*} \\
\mathrm{X}\end{array}$} & Between & (Combined) & 4966,227 & 28 & 177,365 & 9,911 & ,000 \\
\hline & & Linearity & 3723,893 & 1 & 3723,893 & 208,083 &, 000 \\
\hline & & $\begin{array}{l}\text { Deviation } \\
\text { from } \\
\text { Linearity }\end{array}$ & 1242,334 & 27 & 46,012 & 2,571 & ,009 \\
\hline & Within G & & 465,300 & 26 & 17,896 & & \\
\hline & Total & & 5431,527 & 54 & & & \\
\hline
\end{tabular}

Jika nilai signifikansi pada Deviation from linearity $>0,05$ maka kedua variabel berhubungan secara linier. Dari hasil analisis di atas diketahui bahwa kebiasaan belajar memperoleh Deviation from linearity dengan sig. 0,09>0,05. Dengan demikian Pelaksanaan Pengalaman Lapangan Industri terhadap Kesiapan Memasuki Dunia Kerja bersifat linear.

\section{Pengujian Hipotesis}

Hipotesis diajukan adalah terdapat kontribusi Pelaksanaan Pengalaman Lapangan Industri terhadap Kesiapan Memasuki Dunia Kerja Mahasiswa. Besarnya kontribusi variabel $\mathrm{X}$ terhadap $\mathrm{Y}$ dapat dilihat pada tabel 8 . 
Tabel 8. Analisis Korelasi dan Regresi Sederhana Pelaksanaan Pengalaman Lapangan Industri

(X) Terhadap Kesiapan Memasuki Dunia Keja (Y)

\begin{tabular}{ccccccc}
\hline Model & $\mathrm{R}$ & R Square & $\begin{array}{c}\text { Adjusted R } \\
\text { Square }\end{array}$ & $\begin{array}{c}\text { Std. Error of the } \\
\text { Estimate }\end{array}$ & & \\
\hline 1 &, $828(\mathrm{a})$ &, 686 &, 680 & 5,67622 & & \\
Model & & Sum of & Df & Mean Square & F & Sig. \\
& & Squares & & & & \\
1 & Regression & 3723,893 & 1 & 3723,893 & 115,579 &, $000(\mathrm{a})$ \\
& Residual & 1707,634 & 53 & 32,220 & & \\
& Total & 5431,527 & 54 & & & \\
\hline
\end{tabular}

Tabel Di atas menunjukkan bahwa harga koefisien korelasi antara Pelaksanaan Pengalaman Lapangan Industri (X) dengan Kesiapan Memasuki Dunia Kerja (Y), r adalah 0,828 dengan harga keberatian probabilitas sebesar 0,000 pada alpha 0,05. Hal ini berarti bahwa nilai probalitas sebesar $0,000<$ taraf alpha 0,05, sehingga Ho ditolak dan Hi diterima. Dengan demikian dapat dinyatakan bahwa terdapat hubungan Pengaruh Pelaksanaan Pengalaman Lapangan Industri Terhadap Kesiapan Memasuki Dunia Kerja Mahasiswa Jurusan Teknik Otomotif FT-UNP secara signifikan pada taraf kepercayaan 95\%. Berdasarkan tabel 8, diperoleh koefisien determinasi $\left(\mathrm{R}^{2}\right)$ sebesar 0,686 . Hal ini menunjukkan bahwa besarnya kontribusi kebiasaan belajar $(\mathrm{X})$ terhadap hasil belajar (Y) sebesar 68,6\%. Untuk mengetahui koefisien regresi yang terbentuk, sebelumnya dilakukan uji-t untuk mengetahui apakah model regresi bisa dipakai untuk memprediksi ubahan hasil belajar (Y).

Tabel 9. Koefisien Regresi Sederhana Pelaksanaan Pengalaman Lapangan Industri Terhadap Kesiapan Memasuki Dunia Kerja

\begin{tabular}{|c|c|c|c|c|c|c|}
\hline \multirow[t]{2}{*}{ Model } & & \multicolumn{2}{|c|}{$\begin{array}{c}\text { R Square Unstandardized } \\
\text { Coefficients }\end{array}$} & \multirow{2}{*}{$\begin{array}{c}\begin{array}{c}\text { Standardized } \\
\text { Coefficients }\end{array} \\
\text { Beta }\end{array}$} & \multirow{2}{*}{$\begin{array}{c}\mathrm{T} \\
\mathrm{B}\end{array}$} & \multirow{2}{*}{$\begin{array}{c}\text { Sig. } \\
\text { Std. Error }\end{array}$} \\
\hline & & $\mathrm{B}$ & Std. Error & & & \\
\hline \multirow[t]{2}{*}{1} & (Constant) & 14,339 & 9,966 & & 1,439 & ,156 \\
\hline & $\begin{array}{c}\text { PELAKSANAAN } \\
\text { PLI }\end{array}$ & ,805 & 075 & ,828 & 10,751 &, 000 \\
\hline
\end{tabular}

Persamaan regresinya sebagai berikut:

$\mathrm{Y}=\mathrm{a}+\mathrm{bX}$

$\mathrm{Y}=14,339+0,805 \mathrm{X}$

Angka-angka ini dapat diartikan sebagai berikut:

- Konstanta sebesar 14,339 artinya jika pelaksanaan pengalaman lapangan indusri (X) nilainya 0 , maka kesiapan memasuki dunia kerja nilainya sebesar 14,339.

- Koefeisien regresi variabel pelaksanaan pengalaman lapanan industri (X) sebesar 0,805 artinya jika kebiasaan belajar mengalami kenaikan satu satuan, maka kesiapan memasuki dunia kerja (Y) akan mengalami peningkatan sebesar 0,805 satuan.

Berdasarkan Tabel 9, maka diketahui t hitung sebesar 10,751 dan $\mathrm{t}$ tabel dapat dicari dengan (df) n-2 atau 55-2 = 53, maka t tabel sebesar 2,005. Oleh karena t hitung $(7,633)>\mathrm{t}$ tabel $(2,006)$ maka Ho ditolak, artinya bahwa pelaksanaan pengalaman 
lapangan industri $(\mathrm{X})$ berpengaruh terhadap kesiapan memasuki dunia kerja (Y). Jadi dapat disimpulkan bahwa pelaksanaan pengalaman lapagan indusrti berpengaruh terhadap memasuki dunia kerja.

\section{Koefisien Determinasi $\left(\mathbf{R}^{2}\right)$}

Mengetahui besar kontribusi yang diberikan oleh variabel bebas terhadap variabel terikat dapat dilihat pada Tabel di bawah ini.

Tabel 10. Uji Koefisien Determinasi Pengaruh Pelaksanaan Pengalaman Lapangan Industri Terhadap Kesiapa Memasuki Dunia Kerja

\begin{tabular}{ccccc}
\hline Model & $\mathrm{R}$ & $\mathrm{R}$ Square & Adjusted R Square & Std. Error of the Estimate \\
\hline 1 &, $828(\mathrm{a})$ &, 686 &, 680 & 5,67622 \\
\hline
\end{tabular}

Koefesien determinanisi Pelaksanaan Pengalaman Lapangan Industri (X) Terhadap Kesiapan Memasuki Dunia Kerja (Y).

$$
\begin{aligned}
\mathrm{KP} & =\mathrm{r}^{2} \times 100 \% \\
& =0,686 \times 100 \% \\
& =68,6 \%
\end{aligned}
$$

Jadi besar pengaruh yang diberikan kebiasaan belajar terhadap hasil belajar 68,6\%.

\section{Pembahasan}

Penelitian ini telah menunjukkan gambaran tentang pengaruh Pelaksanaan Pengalaman Lapangan Idustri (X) Terhadap Kesiapan Memasuki Dunia Kerja (Y) Pada Mahasiswa Jurusan Teknik Otomotif FT-UNP. Rangkuman analisis korelasi sederhana dan ganda dapat dilihat pada Tabel 11.

Tabel 11. Rangkuman Analisis Korelasi Sederhana

\begin{tabular}{cl}
\hline Variabel & \multicolumn{1}{c}{$\mathrm{X}$ dan $\mathrm{Y}$} \\
\hline \multirow{3}{*}{ Korelasi Sederhana } & $\mathrm{R}_{\mathrm{xy}}=0,828$ \\
& $\mathrm{R}$ Square $=0,686$ \\
& $\mathrm{Sig}=0,000$ \\
\hline
\end{tabular}

Berdasarkan rangkaian analisis data penelitian, ditemukan bahwa terdapat pengaruh antara Pelaksanaan Pengalaman Lapangan Industri (X) Kesiapan Memasuki Dunia Kerja (Y) dengan koofisien korelasi 0,828 dan koefisien determinasinya 0,686 yang mempunyai arti kebiasaan belajar memberikan kontribusi sebesar 68,6\% terhadap hasil belajar setelah melakukan uji signifikan pada taraf 5\%. Dengan demikian Pelaksanaan Pengalaman Lapangan Industri membeikan pengaruh terhadap Kesiapan Memasuki Dunia Kerja. Pada analisis ini Pelaksanaan Pengalaman Lapangan Industri hanya memberikan pengaruh sebesar $68,6 \%$ hal ini diduga adanya faktor-faktor lain yang tidak diteliti. Sebagai gambaran mengenai Pelaksanaan Pegalaman Lapangan Indstri yang diperoleh berdasarkan persentase pencapaian responden maka Pelaksanaan Pengalaman Lapangan Industri dapat dikategorikan cukup baik. 
Dari hasil penelitian di atas dapat diketahui bahwa pelaksanaan Pengalaman Lapagan Industri mempengaruhi kesiapan mahasiswa memasuki dunia kerja. Dimana semakin baik pelaksanaan Pengalaman Lapangan Industri maka akan semakin baik pula kesiapan mahasiswa dalam memasuki dunia kerja. Untuk meningkatkan kesiapan mahasiswa memasuki dunia kerja, maka mahasiswa harus memahami Pelaksanaan Pengalaman Lapangan Industri dengan baik. Dengan adanya pengetahuan tentang pelaksanaan Pengalaman Lapangan Industri maka mahasiswa akan lebih siap dalam menghadapi persaingan didunia kerja. Hal ini sesuai dengan hasil dari beberapa penelitian sebelumnya [8],[9],[10],[11] dan [12].

\section{KESIMPULAN}

Penelitian ini bertujuan untuk mengungkapkan pengaruh pelaksanaan penglaman lapangan industri terhadap kesiapan memasuki dunia kerja pada mahasiswa Jurusan Teknik Otomotif FT-UNP. Berdasarkan hasil penelitian dan pembahasan maka dapat disimpulkan sebagai berikut.

Pertama terdapat pengaruh yang signifikan antara Pelaksanaan Pengalaman Lapangan Industri Terhadap Kesiapan Memasuki Dunia Kerja Pada Mahasiswa Jurusan Teknik Otomotif FT-UNP terlihat pada hasil uji koefisien determinasi sebesar 0,828 sementara nilai $\mathrm{R}$ tabel sebesar 0,266 maka $\mathrm{R}$ hitung > $\mathrm{R}$ tabel. Hal ini berarti terdapat hubungan positif dan signifikan antara pelaksanaan pengalaman lapangan industri dengan kesiapan mahasiswa memasuki dunia kerja.

Kedua, Terdapat kontribusi Pelaksanaan Pengalaman Lapangan Industri terhadap Kesiapan Memasuki Dunia Kerja Mahasiswa Jurusan Teknik Otomotif FT-UNP sebesar $68,6 \%$.

\section{REFERENSI}

[1] Wariati, Nana. 2015. Pengaruh Disiplin Kerja dan Pengalaman Terhadap Kinerja Pegawai Dinas Pendapatan Pengelolaan Keuangan dan Aset Kabupaten Barito Timur. Jurnal Wawasan Manajemen. 3 (3). 220

[2] Oemar Hamalik. 2005. Manajemen Kepelatihan Ketenaga Kerjaan. Bandung: Citra Aditya Bakti

[3] Pratama ,Y dkk. (2018). Hubungan Praktik Kerja Industri Dengan Kesiapan Kerja Siswa SMK Negeri 1 Cibinong Kelas XII Kompetensi Kahlian Teknik Gambar Bangunan. Jurnal pensil : Pendidikan Teknik Sipil, 7(1), 53-62. https://doi.org/10.21009/pensil.7.1.6

[4] Wibowo. 2016. Manajemen Kerja. PT. Raja Grafindo Persada. Jakarta-14240

[5] Djuwita, Efriyani. (2003). Memilih dan mencari kerja sesuai dengan bakat dan kepribadian. Jakarta: Kawan Pusaka

[6] Ginting, Desmon. 2016. Panduan Menjadi Karyawan Cerdas. Jakarta: PT. Elex Media Komputindo

[7] Suharisimi Arikunto. 2016 Prosedur Penelitian Suatu Pendekatan Praktek. Jalarta: Rineka Cipta

[8] Rahman, A., Maksum, H., \& Putra, D. (2018). KONTRIBUSI PENGALAMAN AFEKTIF PRAKTIK KERJA INDUSTRI TERHADAP KESIAPAN SISWA MEMASUKI DUNIA KERJA KELAS XII JURUSAN TEKNIK KENDARAAN RINGAN DI SMK N 1 TILATANG KAMANG. Automotive 
Engineering Education Journals, 7(1). Retrieved from http://ejournal.unp.ac.id/students/index.php/poto/article/view/3322

[9] Simanungkalit, R. (2013). Pengaruh Motivasi Memasuki Dunia Kerja dan Pengalaman Praktik Kerja Industri Terhadap Kesiapan Kerja Siswa Kelas XI SMK Citra Harapan 1 Percut Sei Tuan TA 2012/2013 (Doctoral dissertation, UNIMED).

[10] Rosara, D. B., \& Nugroho, J. A. (2018). Pengaruh Pengalaman Praktik Kerja Industri dan Motivasi Memasuki Dunia Kerja terhadap Kesiapan Kerja Peserta Didik SMK Kristen 1 Surakarta Tahun Angkatan 2017/2018. Jurnal Pendidikan Bisnis dan Ekonomi, 4(1).

[11] Sari, Y. (2020). Pengaruh Pengalaman Lapangan Industri terhadap Kesiapan Kerja Mahasiswa Program Studi D4 Manajemen Perhotelan Angkatan 2015 Universitas Negeri Padang. Jurnal Kajian Pariwisata dan Bisnis Perhotelan, 1(2), 77-81.

[12] Yustati, H., \& Auditya, L. (2019). Pengaruh Praktek Pengalaman Luar, dan Motivasi Masuk Dunia Kerja Terhadap Kesiapan Kerja Mahasiswa Perbankan Syariah di Lembaga Keuangan Syariah. JABE (Journal of Applied Business and Economic), 6(1), 45-53. 